\title{
Influence Management and Skill Teachers Class Teaching Students to Study Results
}

\author{
Entriyani $^{\left.1^{*}\right)}$, Yasir Arafat ${ }^{2}$, Syaiful Eddy ${ }^{2}$ \\ ${ }^{1}$ SMP 1 Plakat Tinggi, South Sumatra, Indonesia \\ ${ }^{2}$ Universitas PGRI Palembang, Indonesia \\ ${ }^{*}$ Corresponding Author. Email: entrimulyonosmp1@gmail.com
}

\begin{abstract}
This research aims to review the influence of the management class and skill of teachers in together against learning outcomes students. The study was conducted in public junior Plakat Tinggi District county superior Musi Banyuasin. This research is kind of quantitative research with the design of the research uses expo-facto. Included in this research is a total of all teachers in public junior Plakat Tinggi District county superior Musi Banyuasin consisting of two teachers. The survey data collection techniques using, documentation and. Observation Data analysis techniques using a technique descriptive, quantitative analysis and of multiple regression. The results of this research stated that there is significant influence: (1) between management class of learning outcomes students; (2) is significant influence in the teaching of skill teachers in learning students; and (3) is significant influence together between management and skill teachers class teaching students to study results.
\end{abstract}

Keywords: Management, Skill Teacher, Result Study

\section{INTRODUCTION}

To implement his duty. The, and educators especially one intended for these teachers in desperate need of all kinds of knowledge [1]. Knowledge, skill, and the ability of professional event should always be increased specially to prepare human resources able to face the world competition next years to come. It is said that skill or skill teachers also need to be increased again because teachers have importance in education. Think of the importance and responsibility in the heavy teachers to educate participants students.

Knowledge, skill, and the ability of professional event should always be increased specially to prepare human resources able to face the world competition next years to come. It is said that skill or skill teachers also need to be increased again because teachers have importance in education. Think of the importance and responsibility in the heavy teachers to educate participants [2].

Various efforts innovation that produces improve the quality of unrelenting done. The goal among others, that the results better, increase, and more productive of a previous state. Of all those changes that is new paradigm to exert an influence upon the life of nation and state. The impact is felt by various parties, both government and nongovernment, which is the private and the public. Although it is still in the standard, but has opened the horizon ideas or valuable ideas in preparing the implementation of national education the systems of law.

One of the problems facing the world our education is weak learning. School tuition to the learning process less driven to develop the capacity to think. Learning in the classroom handed to a generation of kids able for memorization information without are required to understand and connecting information with daily life. As a result, school tuition only having knowledge theoretically, but it capable of application in daily life. View's constructivism said, that strategy acquire more precedence than how much school tuition obtain and recall the knowledge of. Implications, teachers not only the information or material learning, but better as those motivators activatable school tuition to cultivate information or material learning through a process seek and experienced. 
Learning environment good support students learning to follow with good. Class and not conducive environment will make students uncomfortable in learning, even allow to students to do the things that way and in learning problems. A professional teacher will complete must be themselves to skills is expected to help in carrying out their duties. Basic skills teaching is skills must be absolutely belonging to a teacher. Possession basic skills are expected to teach this teacher optimize role in the classroom [2].

One scope management education needs to be governance is the place for that is the creation of the learning process. Learning the great lessons vitiated, the readiness of the system, the classes are safe, comfortable, and a good social interaction.

Management class is a conscious effort to maintain the learning process systematically.

If a teacher does not use skill in learning, it will make students become quickly bored, factors that often being a bully in the learning process is the boredom students. The board of the class as management education, aimed at: (a) realization of the learning and active learning, creative, effective, fun, and meaningful, (b) the creation of students active develop the potential himself, (c) competence managerial educators as manager, (d) the achievement of the purpose of learning effectively, (e) educators with the theory about the process and tasks administration class, (f) problems study results school tuition, $(\mathrm{g})$ the creation of planning learning quality, and improve the image of positive education.

Ideally, the better teachers applying management class, the more easily teachers teaching skills apply, and the good students learning outcomes, effective so teachers are teachers who can apply expertness or skill management class and teaching good for applied learning through various strategies that students achieve their learning levels or achieve competence as planned.

Better management teachers apply class, so easily teachers should apply skills, and the better also study results students, so teachers effectively were teachers that can apply management classes and expertness or skill teaching good for applied through various strategies learning that students reach out to learn optimally or reach competence according to plan.

Management education, aimed at: a realization of the learning and active learning, creative, effective, fun, and meaningful, (b) the students active the potency of himself, (c) managerial competence educators as manager, (d) efficiency effectively achieve the purpose of learning, (e) educators with the theory of the class and administrative tasks, (f) problem students learning outcomes, (g) planning the creation of quality learning, and $(\mathrm{h})$ boost positive education.

Ideally, both teachers apply the management class, easy as the more teachers and skill, and the good students study results, so teacher's effective management are teachers who apply class and teaching expertness or skill to apply through various learning strategies so students achieve optimal learning or reach as planned. The class management based on a theory and manifested teachers in learning that the class conducive, facilities and infrastructures, the learning light and devices, the learning and the management of students as one factor supporting learning activities in class.

An effective teacher, in addition to apply management class, also have skills teaching was the teachers to achieve effective learning. Various kinds of skills we should be controlled theory teachers based on which there is opening and closing learning, explained, question and answer, give variations stimulation, to strengthening, guiding a small group, small groups and individual teaching, and manage the learning process. All skill taught in class play an important role in the outcomes of learning students.

Teaching and learning activities will run well and be successful if someone who teaches subjects already owns and controls teaching skills may open learning well and can use the media to respond to students with positive behavior and may provide a stimulus and be able to provide explanations to improve the quality of reasoning students.

\section{METHODS}

\subsection{The Type of Research}

This study, use of the qualitative study with a view to gain an understanding of the meaning of and their deep phenomenon in the field.

\subsection{The Subject of Research and Data}

The subject of study is all teachers in public primary schools 15 Betung. The data collection was done using interviews to teachers in terms of ability to teach teachers in managing classes in public SMPN 15 Betung Banyuasin district in terms of: planning learning, the execution of learning, the activity of when teachers given the lectures learning, teachers given the lectures learning is varied between, skill the teacher asks, and the strengthening.

\section{RESULTS AND DISCUSSION}

Teaching is all deliberate efforts in order to give opportunity for the school tuition to come the learning process consistent with the objectives of which was formulated. Therefore, activity is prominent to the learning process that is school tuition. 
To implement the profession, so of teachers especially one intended in these teachers need green and luscious [3]. Knowledge, skill, and the ability always improved professional should be especially in preparing human resources able to face the world next year's competition will later. Be said that skill or skill was also need to improve because teachers have importance in education.

The importance left duties and responsibilities to teachers heavy enough to participants [4]. Training school principals to teachers must optimal through the learning at the school and must cope with the more transformational leadership set at the school. To improve the performance of teachers and so biased realized the quality of lessons learned to increase the quality of education. To enhance the quality of national education, have to get special attention as the class learning, because has created the knowledge on students.

One of that should be owned by teacher's professional education to effective teaching the skill. Based on the research teachers have implemented teaching high skill excellent. Results supported [5] that to improve the education quality should obtained from superior, human resources intellect, of a morality, spirituality, professionalisms and ability the competitiveness and competence [6]. Human resources management must actively involve in planning, in a management and control the learning outcomes students [7], [8], [9]. And in research study results SMPN in the Plakat Tinggi district, positively through increased management teaching class and skill teachers. Data is obtained from a collection of the average score students study results with value very good especially in the science have done.

Looking at the analysis of data about student's study results in SMPN in the Plakat Tinggi district many factors or of the level of student's study results of factors such the school, teachers, development curriculum, more time learning, students and psychological factors itself, intelligence [10], [11], [12], for example the motivation to study, their interests and talents. This study supported by research journal on improvement skill ask questions and students study results, learning outcomes are achieved students learning achievements in the process learning activities with a change and the formation of one behavior. To declare that a process of learning can be said work, every teacher has a view part in line with his philosophy [13], [14], [15]. But to equalize perception we should aim for the curriculum in effect today which have been refined [16], [17], among other things that a process of learning and teaching about an ingredient of learning expressed work if the goal of learning especially can be achieved. The results of the above analysis, so can be said that the management class and skill of teachers work together for the study of SMPN in the Plakat Tinggi district Musi Banyuasin.

\section{CONCLUSION}

Conclusions on this research is: students learn in SMPN the Plakat Tinggi district. There is a significant influence between management class size on learning outcomes students in SMPN the Plakat Tinggi district. There is significant influence between teaching teachers on the skills students learn in SMPN the Plakat Tinggi district. There is significant influence in together between management classes and teachers teaching on the skills

\section{REFERENCES}

[1] Fitria, H., Kristiawan, M., \& Rahmat, N. (2019). Upaya Meningkatkan Kompetensi Guru Melalui Pelatihan Penelitian Tindakan Kelas. Abdimas Unwahas. 4(1), 1-14

[2] Djamarah S.B. (2005). Guru dan Anak Didik dalam Interaksi Edukatif Suatu Pendekatan Teoritis Psikologis. Jakarta: Rineka Cipta

[3] Fitria, H., Kristiawan, M., \& Rahmat, N. (2019). Upaya Meningkatkan Kompetensi Guru Melalui Pelatihan Penelitian Tindakan Kelas. Abdimas Unwahas. 4(1), 1-14

[4] Djamarah S.B. (2005). Guru dan Anak Didik dalam Interaksi Edukatif Suatu Pendekatan Teoritis Psikologis. Jakarta: Rineka Cipta.

[5] Utami R.,Ahmad S., \& Eddy S. (2020). Implementasi Manajemen Sumber daya Manusia. Journal of Education Research. Vol.1.No.3.Pages 226-236

[6] Astuti, M. S. (2015). Peningkatan keterampilan bertanya dan hasil belajar siswa kelas 2 SDN Slungkep 03 menggunakan model Discovery Learning. Scholaria: Jurnal Pendidikan Dan Kebudayaan. Vol.5. No.1. Hal.10-23.

[7] Kusumaningrum, D. E., Arifin, I., \& Gunawan, I. 2017. Pendampingan pengembangan perangkat pembelajaran berbasis Kurikulum 2013. ABDIMAS PEDAGOGI: Jurnal Ilmiah Pengabdian kepada Masyarakat, 1(1).

[8] Kusumaningrum, D. E., Sumarsono, R. B., \& Gunawan, I. 2017. Problematika Pemberdayaan dan Pengembangan Sumber Daya Manusia di Sekolah Menengah Pertama Berbasis Pesantren. Ilmu Pendidikan: Jurnal Kajian Teori dan Praktik Kependidikan, 2(2), 139-150.

[9] Gunawan, I., Triwiyanto, T., \& Kusumaningrum, D. E. 2018. Pendampingan penulisan artikel ilmiah bagi para guru sekolah menengah pertama. Abdimas Pedagogi: Jurnal Ilmiah Pengabdian kepada Masyarakat, 1(2), 128-135. 
[10] Sultoni, S., Gunawan, I., \& Sari, D. N. 2018. Pengaruh Etika Profesional Terhadap Pembentukan Karakter Mahasiswa. JAMP: Jurnal Administrasi dan Manajemen Pendidikan, 1(3), 279-283.

[11] Suminah, S., Gunawan, I., \& Murdiyah, S. 2018. Peningkatan Hasil Belajar dan Motivasi Belajar Siswa melalui Pendekatan Behavior Modification. Ilmu Pendidikan: Jurnal Kajian Teori dan Praktik Kependidikan, 3(2), 221-230.

[12] Gunawan, I., Ulfatin, N., Sultoni, S., Sunandar, A., Kusumaningrum, D. E., \& Triwiyanto, T. 2017. Pendampingan Penerapan Strategi Pembelajaran Inovatif dalam Implementasi Kurikulum 2013. Abdimas Pedagogi: Jurnal Ilmiah Pengabdian kepada Masyarakat, 1(1).

[13] Gunawan, I. 2009. Hubungan keterlibatan guru dalam musyawarah guru mata pelajaran dan kemampuan mengelola kelas dengan motivasi belajar siswa di SMA Negeri se-Kota Malang/oleh Imam Gunawan (Doctoral dissertation, Universitas Negeri Malang).

[14] Zahro, Z. R., Andriningrum, H., Sari, E. P., \& Gunawan, I. (2017, November). Sekolah Siaga Bencana: Kajian Evaluatif Kesiapsiagaan
Sekolah Menghadapi Bencana. In Seminar Nasional Pendidikan Sinergitas Keluarga, Sekolah, dan Masyarakat dalam Penguatan Pendidikan Karakter, Fakultas Ilmu Pendidikan Universitas Negeri Malang, Malang, Indonesia (pp. 249-258).

[15] Andriningrum, H., \& Gunawan, I. (2018, December). Cultivatation of Healthy Life for Students in School: A Literature Review. In International Conference on Education and Technology (ICET 2018). Atlantis Press.

[16] Argadinata, H., \& Gunawan, I. (2019, December). The Leadership of Pancasila in Education: Foundation for Strengthening Student Characters in the Industrial Revolution Era 4.0. In the 4th International Conference on Education and Management (COEMA 2019). Atlantis Press.

[17] Saputra, B. R., Adha, M. A., Ariyanti, N. S., \& Gunawan, I. (2019, December). Tips for Principal in Managing One Roof School (SATAP) in Underdeveloped Area. In the 4th International Conference on Education and Management (COEMA 2019). Atlantis Press. 